\title{
“A Flaw Not Only In Him": Rereading Thomas Pynchon
}

\section{Douglas Keesey}

[Pynchon's] three books... are weak in at least the sense that they are susceptible to no one certain outline of an interpretation: that is to say, they lack emotional power, and all feeling is bogged down in intricate cerebral detail. Many readers find them tedious and unreadable!

More starkly than most, Martin Seymour-Smith states the problem that many critics have had with Pynchon: the elaborate detail in his fiction seems to work against any "certain" interpretation. Pynchon seems more interested in filling his works with isolated bits of information than in creating sympathetic characters whose stories we can follow. As Seymour-Smith puts it, "gobbets of what look like undigested knowledge hang about and clutter up the flow of Pynchon's undoubtedly manic inventiveness." 2 Critics find Pynchon hard to swallow because he has not properly "digested" his facts so that they may "flow" as fiction. The bits of information Pynchon provides do not cohere; the main subject of his fiction cannot be determined; hence, Pynchon cannot possibly be considered a "great" writer. In a telling juxtaposition, Seymour-Smith describes Pynchon as a writer "who cannot be categorized-and whose impact is by now fast diminishing."' Pleased 
that Pynchon's uncategorizable fictions are no longer sowing confusion among future writers, Seymour-Smith concludes with a most definite categorization (again, his word) of Pynchon's value: "Of course Pynchon is not 'great' or even almost great: he is not in that category." 4 Though obviously overstated, Seymour-Smith's charges against Pynchon are serious and deserve equally serious attention. Those of us who believe that the "intricate cerebral detail" of Pynchon's fiction is intimately involved in the creation of multi-dimensional characters must do more than give brief lessons in statistics, thermodynamics, and information theory; we must show how the many scientific (and other) allusions work in very complex ways to define character just as characters may work to redefine their scientific (and other) contexts. The elusive subject of Pynchon's fiction will then be seen to be subjecivity itself - the ways in which scientific, social, sexual, and literary forms characterize the self as a coherent (or incoherent) entity, and the ways in which that self may try to remake the very forms by which it is constituted.

The trouble some critics have had in trying to categorize Pynchon is due to the fact that his fictions challenge-radically-many of the categories these critics accept as a given: a reasonably clear narrative structure or "flow;" allusions that do not come so thick and fast that they "bog down" the story's progress or impede identification with its characters; a work of fiction that separates its main subject from all the other possible subjects of fiction and does not get lost in a jumble of too many big themes. But Pynchon's subject is that constant interpenetration of different categories, forms, and contexts, and the way in which character is the intersection both controlled and controlling of these forms. The identification he expects us to make is with these intersected and-secting characters, with their attempt to find a suitable context in which to place themselves and join with a not-too-different other.

Critics who have had trouble categorizing Pynchon's three novels, particularly the kaleidoscopically allusive, 760-page Gravity's Rainbow, have naturally turned to Pynchon's short fiction for help. "Entropy" has proven the favorite, anthologized and discussed more often than any other Pynchon short story because, as one critic put it, "The significance of the story grows, in retrospect, as an aesthetic source and a preface for the novels that follow. In contrast to their uncertainties, this work is almost proverbial in its clarity and simplicity." With its contrapuntal or fugal structure, ${ }^{6}$ "Entropy" has served numerous critics as the strong, clear source ("almost pro-verbial") against which to understand all the complex words that came after. Downstairs is Meatball Mulligan, who tries to impose some kind of order on a "leasebreaking" party that is fast degenerating into chaos, while upstairs we find Callisto and Aubade, who work desperately to keep chaos from entering their exquisitely ordered world. Mulligan succeeds in creating order because he is not afraid of hard work, while Callisto gives up and allows chaos to overwhelm him.

This is the story as it has been told-categorized-by many a 
critic, generally with the purpose of "providing any early example of Pynchon's treatment of [fill in the blank with any major theme]." The problem with readings of this kind is that, while they may seem to provide some framework in which to understand the notoriously hardto-delimit Gravity's Rainbow, they are in fact as reductive of "Entropy" as they will be of Pynchon's later works, for "Entropy" is, in ways we shall see, quite complex in its own right. If it can be called a "source" for Pynchon's later writings, that is because this short story is, like the works to come, packed full of allusions to many different contexts, scientific, social, sexual, and literary, no one of which should be arbitrarily isolated from the others, for the point of the story lies in their intersection.

What follows is an attempt to describe the complex relationship between character and the contexts in which it finds itself made and which it would like to change in order to remake itself. I begin by suggesting a reason for what none of these critics seems able to account for: exactly why does Callisto give up and allow the forces of "entropy" to engulf him? I argue that his resignation is really a last desperate attempt at resistance, the means by which he intends not to lose, but to triumph over chaos. This new interpretation of the end of the story then leads to a reconsideration of its beginning and middle, to a discussion of how Callisto's polarizing consciousness is both constituted by and continually reconstitutes his surrounding contexts - philosophical, scientific, sexual, historical, and literary. I will show how Callisto's abstract divisions between free will and chance, order and entropy, male and female, and his equally abstract identifications between past and present, between life and a certain kind of art, lead to his final decision that the only happy context for him, the only state in which what he fears will be kept away and what he desires joined to him, is that of death. My argument, because it is about the relationship between contexts, will call attention to such things as the gender coding of Callisto's philosophical concepts, the rhetorical nature of his sexual beliefs, and the history of his attitudes toward literature. I hope to demonstrate that it is only by attending to Callisto's interaction with all these contexts that we can come close to understanding his actions in the story, particularly his decision to commit suicide. ${ }^{7}$

Callisto negates himself in order to beat the forces of negation; he jumps to conclusions so that he will not have to suffer being pushed. And this preemptive strike against the self is not only meant to forestall an attack from the other (what is left of the self for the other to destroy?), but also to seize for the self the other's power, to place the self in a position of dominance like that of the other. By "making like" the other, the self hopes to assimilate its power; by destroying himself ahead of time, the son tries to wrest the scythe from Father Time. ${ }^{8}$ The activity of self-demolition may be the only freedom from passivity before the other's destructive force; if one has not the strength to live, perhaps exerting one's will to die will bring a whole new life. If the self must fail in its attempt at purity because of the constant contamination by a soiled other, why not permit oneself to be saturated, completely defiled 
so as to acquire the other's transcendent order, wholly corrupted so as to be broken into a new sense of self-unity?

Having first assumed that the other is all-powerful, one then assumes the other-absorbs the other's power by being absorbed into it. The assumption concerning the other's omnipotence is really one with the self's desire for absolute power. The self only "sees" the other through the mirror of its own fear and desire, the fear of being overtaken (by the other, by time) provoking the desire to take over. We could say that for the self illusion fosters illusion, that idealism produces nihilism which gives rise to still more idealism: the assumption that the omniscience and omnipotence lacking to the self inhere in an "other" leads to the assumption that if one assimilates the other (or, what amounts to the same thing, if one negates oneself in order to be assimilated by the other), then one can fill that lack and be whole like the "other."

But the self must never admit the possibility that it may have made an unwarranted assumption, that the idealizing categories through which it views the other may be more of a mirror than a window, more narcissistic fantasy than self-confirming truth. If the other were truly other than what the self desires, if the threat it posed to the self were any less great than that with which the self would want to menace the other, then how could the self hope to achieve its ideal of omnipotence through self-annihilation? The masochistic self must believe in the existence of a sadistic other who will impose restraints so severe that the masochist will be sure of the sadist's power, certain of the omnipotence with which the masochist himself would identify. The self can turn bondage into freedom; it can rewrite a play in which it has an assigned part. But uncertainty as to the other's authority frees the self only to doubt, gives the self the task of revising a play written in a language the self may not know. Knowledge of one's limits can always be reconverted into power, but the lack of certainty only reinforces the self's fear of a basic lack of power. To admit the possibility that one's knowledge may be limited would thus be to confess to the worst of possible limitations, for an uncertain limit is like a contest that no one can win because no one knows the rules, or like an hourglass that cannot be turned over again because one cannot tell when the sand has run out. In order to maintain its definition of the other as filling for the self's lack of being, as the transcendental signified to which everything in the self points, the self must continually deny the possibility that it may not know the significance of the other: what if the self merely slips from signifier to signifier without ever finding the locus of power it seeks? The endless defile of the signifier would be the worst possible defilement of the self's purity of meaning; every time that the self thinks it has found fulfillment in an other, it may only have discovered another avoidance of power. To entertain the possibility of a limit to the self's knowledge is thus to occupy oneself with something that cannot be held in place; to introduce the idea is to admit something that cannot be taken in if the self is to remain itself: uncertainty about the 
other is truly destructive in that it confounds the self's faith that it knows itself.

This aversion to an uncertain limit explains why Callisto in "Entropy" is so quick to accept a hopelessly pessimistic view of the other and the future as the truth: strangely, pessimism is his only hope; the certainty of his total estrangement from both the other and the future is the closest he can get to grasping them. The possibility that his words may be inadequate to an understanding of the world, that his negative reduction of the situation might be just that $-a$ reduction, is barely raised before being repressed as more dangerous than the certainty of danger:

He was aware of the dangers of the reductive fallacy and, he hoped, strong enough not to drift into the graceful decadence of an enervated fatalism. His had always been a vigorous, Italian sort of pessimism: like Machiavelli, he allowed the forces of virtu and fortuna to be about 50/50; but the equations now introduced a random factor which pushed the odds to some unutterable and indeterminate ratio which he found himself afraid to calculate.["Entropy:" $87-88 / 73]^{10}$

Callisto goes on to decide that "that constant 37 [degrees Fahrenheit] was now decisive" (E: $98 / 85)$, to determine that because the temperature outside his window hasn't changed for three days the homogeneity is now terminal: the universe is dying of entropy. And, in a "sudden" and decisive blow, Callisto's lover Aubade breaks the window separating their "Hermetically sealed" room from the "vagaries of the weather," their "tiny enclave of regularity" from the "city's chaos" (E: 83-84/68), so that " 37 degrees Fahrenheit should prevail both outside and inside, and forever" (E: 98/85-86).

Concerned about preserving his "virtu" or virility, Callisto never felt unduly threatened by "fortuna" or lady luck because he always thought he knew her, that he possessed basic knowledge of the limits of her power: his "vigorous, Italian sort of pessimism" was more like a cleverly disguised form of optimism; his statement that he "allowed the forces of virtu and fortuna to be about 50/50" means less that he admitted the ratio than that he permitted it. But "fortuna" refuses to accommodate herself to the phallocratic order; against all likelihood, nature remains at 37 degrees for three days in a row, thus asserting that she is not merely the mirror of man's desires. By disturbing the male ratio, she shakes his faith in his ratiocinative powers; an "unutterable and indeterminate ratio" simply cannot be reasoned with or away. "Afraid to" speak the name or "calculate" the force of "fortuna," Callisto is in danger of having his tongue and counting fingers cut off by the other sex; suddenly feminine irrationality disrupts the male body. For Callisto, to " $f[i] n d$ himself afraid to calculate" is to find himself unmanned!"

It is just at this point that Callisto commits his most audacious act - a last, desperate attempt to regain the virility he fears to have lost: 
before "fortuna" can unman him, he castrates himself to show that he is still the one wielding the knife; before chance can destroy his reason, he self-destructs to prove that he can comprehend randomness, expect the unpredictable. Rather than quake before odds that may be worse than " $50 / 50, "$ Callisto stands firm in the belief that he will not survive. If there is no chance for Callisto, then there is no chance ("fortuna") for Callisto: if death can be known, it need not be feared. The smashing of the window to let "chaos" in to the "Hermetically sealed" room is merely the physical confirmation of a psychological self-destruction: before the glass partition is broken and the "vagaries of the weather" disrupt the controlled "regularity" of the room, Callisto has already decided that the glass will not hold ("[in] his obsession ... that constant 37 was now decisive"'). In his imagination of certain destruction by the other, he has theoretically already committed suicide. The gap between envisioning one's inevitable destruction and suffering it blindly is introduced by Callisto as a saving grace (period): as long as he has time to see the castration by which the member separating him from a "s/he" will be removed, he can still believe that "he" remains virtually intact; that if his member is taken it is solely by his own permission; that his member may be gone but not his membership in the gender of power.

Calisto thus reduces the complexity of "fortuna," the indeterminacy of the other and the future, to the fearsome type of a castrating female because this is the least dangerous figure he can imagine: with it in mind he will at least have something known against which to take action, even if precisely what he knows is that there is no worse im. aginable, that there exists nothing so terrible as to be beyond the bounds of his imagination. Though "He was aware of the dangers of the reductive fallacy and, he hoped, strong enough not to drift into the graceful decadence of an enervated fatalism," Callisto's fatalistic reduction of "fortuna" is actually designed to preserve his phallic potency, to enable meaningful action where none before was possible; nature cannot be beaten at her own game unless man knows the rules; for Callisto to kill himself now would be senseless if nature were not just about to usurp his power of self-determination. Callisto's reductive phallacy works by assigning the phallus to mother (nature) only so that he may reclaim it for himself; the omnipotence that he so desires but fears he lacks is "found" in the other only so that he may take it away. Callisto's hysteron proteron, his assuming as true what has yet to be proved ("that constant 37 was now decisive") and his placement of the weaker sex as first in power, is thus a clever attempt to deny that "truth" and to overturn that "dominance": by defining "power" in his own polarized terms, Callisto hopes to assure himself of the poles' reversibility; if he can let woman go first, that shows his power as a man.

But Callisto must also hide from himself the phallaciousness of his reasoning: to believe in his own virility he must deny that his view of woman is merely a male fantasy. If "she" does not possess the castrating knife, then who will "he" get it from (be castrated by, wrest power from)? If man's hysteron proteron is merely phallacious, then what 
are the terms of argument by which man can prove his power? Callisto's reductive phallacy is thus revealed to be a defense against his real castration anxiety: that woman too may lack the phallus; that the power man seeks may not be obtainable from her; that man may have been cut off at birth from the force he will never understand or master in life. Without the phallus fearfully but really hopefully assigned to her by man, "s/he" is really no other than "he" and will no longer support the illusion of a saving difference. It is significant that the only other that man will accept is a "s/he" so much more powerful than "he" himself, so comprehensibly different, that man feels incited to, and can succeed in, making her power his own. The "s/he" man wants is his exact opposite; the difference he desires is only the one most like himself, the one he likes for being the mirror (enlarged) of his (too small) phallus. Any asymmetrical difference or incalculable otherness is rejected as unrecognizable: man cannot find himself in it, cannot refound himself on surer ground using it as a more stable plan than the original.

Thus Callisto can countenance a "fortuna" exactly like him ("50/50") or a fortune that is his exact opposite (a one-in-a-million chance of survival is no "chance" at all), but he cannot face any less certain figure. Trying to find himself in the other, he prefers a "she" whose weakness can assure him of his own potency (recall that Callisto's pessimistic "50/50" was really a disguised form of optimism), but a strong "she" will do well if not better for then he can find his face in her disfiguring power, his phallus in her knife. Whether Callisto is always at the power-end of the pole or whether he starts in the weak position the better to jump to the dominant end, the one thing he must believe is that the pole exists, that there is a difference between himself and the "other" to be maintained or overcome. If power could not be located at one end or the other, Callisto would not know how to find it; the real lack that Callisto's polarizing consciousness works hard to repress is thus a lack of knowledge, without which power cannot even be identified (defined and made one's own).12

We note too that Callisto's movement from a faith in "equal" odds to a belief in his imminent destruction (and resurrection) is not accidental, but the inevitable effect of his polarizing consciousness, of the way in which he ses his situation. In order to firm up his flaccid sense of self-unity, Callisto hardens his definition of reason and "regularity" so as to stand strong against any possible threat from the other. But the more thoroughly he fortifies himself against the other as a possible threat, the more likely the other is to look like a threat; the narrower his terms of survival, the more likely the other will appear not to fit but to challenge them. So, while Callisto may wish to keep believing that "fortuna" occupies the weak end of the pole across from his position of strength, his own irrepressible fear of weakness will continue to make "fortuna" look stronger and stronger until the odds against him appear overwhelming, at which point he has no choice but to hasten the selfdestruction through which he can identify with her power. The more Callisto self-protectively emphasizes his difference from "fortuna,"the more that very difference undermines his attempt at self-identity, finally 
forcing him to identify with precisely that from which he had originally tried to maintain a difference. The self's polarizing consciousness is thus self-defeating or, as Callisto hopes, the way to self-fulfillment through identification with the other that the self desires. If you can't beat 'em, join 'em as a way of beating them; the other with her threatening difference can be seen as likable if she proves by defeating man to have the power that man wants.

This dynamic of an increasing (imagined) polarization resulting in a final (imagined) unity operates on several levels in "Entropy": between Callisto and "fortuna," Callisto and Aubade, Callisto and the bird he shelters. Just as Callisto's extraordinary desire for survival leads to a proportionately extreme fear of mortality, so his self-defensively strict definition of life (order, reason) makes even the most minor deviations from his norm appear as chaos and irrationality. "The cosmologists had predicted an eventual heat-death for the universe (something like Limbo: form and motion abolished, heat-energy identical at every point in it)" (E: 85/69), but Callisto's fear of this eventuality is so strong that every sign that might point to its coming seems to confirm its occurrence now. So desirous is Callisto of ensuring the preservation of his space in time that he ends up cornering himself in a "Hermetically sealed" room and blinding himself to a future any different from his past (for him, after three days "that constant 37 was now decisive"). The great irony of Callisto's polarizing consciousness is that in its attempt to secure space and time it ends up displacing itself to narrower and narrower confines while terminating its vision of the future to ever shorter periods. The result of this drive for position and persistence is a feeling that there is no time left, no space that can be defended from attack by the other. In fact, Callisto's need for spatio-temporal security is so extreme that he can only see space (true otherness) and time (an unpredictable future) themselves as enemies. The self's only way to security thus becomes self-destruction, the transcendence of all limitation through identifying with the very power to delimit.

Because Callisto cannot accept the "vagaries of the weather" as compatible with or even necessary to the regulation of "order" in his room, because he can only see "fortuna" as "chaos" rather than as a likable or saving difference, he is doomed to usher in the entropy he so fears, to "abolish" his own "form and motion," eradicate his own space and time, in an imitative identification with the supposedly destructive forces of nature. Although he knows that without the introduction of a saving difference entropy will only increase ("the isolated system-galaxy, engine, human being, culture, whatever-must evolve spontaneously toward the Condition of the More Probable" [E: 87/72-73]), it is precisely Callisto's narrow definition of what constitutes "differentiation" and "ordered individuality" that brings on the "sameness" and "chaos" he fears (E: 88/74): by differentiating himself so thoroughly from the other, by viewing all otherness as a threatening difference, he isolates his own system from any beneficial change. Callisto's extreme ideal of order is chaos: any system that cuts itself off from all outside influence in an attempt to become absolutely self-sufficient inevitably 
self-destructs; for a structure to survive, for any order to be maintained, there must be an interdependence of parts. For this reason Callisto's efforts to cut himself off from "that constant 37" as if he could thereby excise the very threat of sameness, as if the process of entropy were a thing that could be cut out, only results in his own mutilation, in an organism so "self-identical" that it is wholly disorganized and cannot survive. In trying to differ/defer the possibly negative effects of space and time, Callisto ends up estranging himself from himself: he becomes the very (dis)embodiment of the destructive process which he had tried to reify and remove as the "other." The only way that Callisto can find to fend off ill fortune and come into his own (lady luck) is to kill the very ego that desires and fears, to abolish the spatio-temporal difference that sustained his attraction and repulsion. Callisto's liebestod with "fortuna" is thus the realization of entropy: "heat-energy identical at every point." His polarizing consciousness destroys the material world in an attempt to bring it into unity.

The attraction-repulsion between Callisto and his lover Aubade mirrors that between the man and Mistress Fortune. Neither wife nor stranger, Aubade makes love with Callisto even as she keeps her distance, desiring meaningful contact but always suspicious of the other's meaning, wanting fulfillment but afraid of any "threat" to her carefully guarded "purity":

The architectonic purity of her world was constantly threatened by such hints of anarchy: gaps and excrescences and skew lines, and a shifting or tilting of planes to which she had continually to readjust lest the whole structure shiver into a disarray of discrete and meaningless signals. Callisto had described the process once as a kind of "feedback": she crawled into dreams each night with a sense of exhaustion, and a desperate resolve never to relax that vigilance. Even in the brief periods when Callisto made love to her, soaring above the bowing of taut nerves in haphazard double-stops would be the one singing string of her determination. [E: 88/73-74]

Desiring to form a new whole with Callisto, Aubade is nevertheless afraid that the attempt will merely destroy her own integrity. The movement of their bodies in love is thus fearfully imagined as a "shifting and tilting of planes to which she had continually to readjust," as "haphazard double-stops"' (two notes produced simultaneously on a string instrument by drawing the bow over two strings at the same time) which constantly threaten her "determination" to remain at "one" with herself. Neither a new creature composed of herself and Callisto nor herself alone, Aubade is caught between structures, feeling the loss of her original unity even as she reaches to draw the other into a new whole. But intercourse for Aubade can only go so far: her narrow definition of integrity makes love the eruption of "gaps" in her otherwise perfect 
intactness; like the ravaging effects of wind and weather, Callisto's desire to join with her only seems to disturb her attempt at selfmonumentalization. "That precious signal-to-noise ratio, whose delicate balance" Aubade feels she must keep is as defensively strict in its definition of "noise" (meaningless and thus potentially harmful signals from the other [E: 92/79]) as Callisto's own "ratio" of odds regarding "fortuna": Aubade's anxiety about Callisto as an embodiment of disorder, a form-splitting motion, matches Callisto's fear of "fortuna" as a castrating female who would have/halve his original wholeness. ${ }^{3}$ Like Callisto, Aubade needs to "reduce" the element of chance in her life to the security of a foregone conclusion: she will only receive the other on her "terms," defining the whole they form together in her way: "the accidental fingers at the small of her back or feathery against her breasts came to her reduced inevitably to the terms of sound: of music which emerged at intervals from a howling darkness of discordancy" ( $E: 84 / 69$ ). Yet Aubade's terms are so rigid they can never be met: there can be no real intercourse between her and Callisto because her extreme fear of disorder makes sexual contact with him seem like the introduction of randomness itself, like a fatal submission to the "accidental" or "haphazard" that would destroy her very sense of self.

If Aubade can only read Callisto's input as incomprehensible, can only see adjustment to him as assimilation by him, it should not be surprising that Callisto finds himself in exactly the same position of confusion or negative ambivalence regarding her: each sees not the other, but the externalization of the self's own fear of externality, of being beside itself; each fears being taken in, not so deeply inside a sheltering other that one feels secure from outside attack, but into the other-as-outside, into the very marginalization that one was trying to avoid. If the "Callisto" that Aubade "sees" is the result of a certain fearful aestheticization of life whereby her lover becomes an opener of "gaps" which threaten her "architectonic purity" or a maker of "noise" which disturbs her musical solo, then Callisto's "Aubade" is likewise a figure of art, a projection of Callisto's own fears as these are given form (and content?) by music and literature. Callisto "finds" his mistress between the covers of a book, "experiences" the meaninglessness of her love through the words of Faulkner, Djuna Barnes, and Henry Miller; the strange choreography to Stravinsky's music dictates the movement toward estrangement in his own relationship with Aubade:

Callisto was trying to confront any idea of the heatdeath now.... He sought correspondences. Sade, of course. And Temple Drake, gaunt and hopeless in her little park in Paris, at the end of [Faulkner's] Sanctuary. Final equilibrium. [Barnes'] Nightwood. And the tango. Any tango, but more than any perhaps the sad sick dance in Stravinsky's L'Histoire du Soldat. He thought back: what had tango music been for them after the war, what meanings had he missed in all the stately coupled automatons in the cafes-dansants, or in the 
metronomes which had ticked behind the eyes of his own partners? .... Stravinsky had managed to communicate in that tango the same exhaustion, the same airlessness one saw in the slicked-down youths who were trying to imitate Vernon Castle, and in their mistresses, who simply did not care. Ma maitresse. Celeste. Returning to Nice after the second war he had found that cafe replaced by a perfume shop which catered to American tourists. And no secret vestige of her in the cobblestones or in the old pension next door; no perfume to match her breath heavy with the sweet Spanish wine she always drank. And so instead he had purchased a Henry Miller novel and left for Paris, and read the book on the train so that when he arrived he had been given at least a little forewarning. And saw that Celeste and the others and even Temple Drake were not all that had changed. [E: 92-93/79-80]

Callisto's modernist literary fathers pass their apocalyptism on to their postmodern reader-son, who seems more than ready to receive their evil tidings. The cultural parents in this passage transmit to Calisto a pessimistic way of seeing, a negative formal reduction of a world in otherwise uncertain motion. ${ }^{14}$ Whether art imitates life or life, art it would be hard to say, for just as the "sad sick dance in Stravinsky's L'Histoire du Soldat" was written to express the real horrors of World War I, so the real-life cafe dancer "Vernon Castle" and his partner Irene press their bodies into the form of a sad sick dance, and just as more live "youths" and their "mistresses" try to imitate Castle and his partner in their dance, so novels are written with characters modeled on these hopeless couples. Life and art "correspond," each confirming the other in a fear that the twentieth century is running down, becoming increasingly disordered or entropic. Callisto and his "maitresse. Celeste" merely extend the terrible rhyme between art and life up through World War II and into the present day, where Callisto and Aubade reduplicate the pattern.15

If Aubade attempts to live her art's narrow conception of formal purity, fearing Callisto's touching "fingers" as "accidental" and his sliding body as "haphazard" as if contact with him meant succumbing to the destructive force of randomness itself, then Callisto also brings strict modernist standards of aesthetic order into his judgment of life, rejecting any real connection with Aubade as if passion meant passivity before the entropic force she embodies. Once he has internalized the modernists' vision of an imminent apocalypse, love can no longer be seen in an unquestionably positive light: "He was forced, therefore, in the sad dying fall of middle age, to a radical reevaluation of everything he had learned up to then; all the cities and seasons and casual passions of his days had now to be looked at in a new and elusive light" (E: 87/73). Love itself comes to seem like a fall into death; "casual passions," like "accidental fingers," threaten to make the self an acci- 
dent or casualty of the other's destructive force. Reading Aubade through Faulkner and the other modernists, Callisto sees a "Temple Drake, Gaunt and hopeless" after being raped by power beyond her control; he sees Aubade as one of the "mistresses, who simply did not care," like his "maitresse. Celeste" who left or died before he could return to find her. To make love with Aubade "means" to become one of those "coupled automatons" whose every move is not the coming together that each desires, but a prechoreographed dance of death dictated by forces beyond their control. Seeing Aubade through art "means" seeing through Aubade to the dire truth behind deceptively attractive appearances, to the "metronome" of death relentlessly "tick[ing] behind [her] eyes." The uncertainty of the living, moving Aubade is formed by Callisto's artistic vision into the certainty of stasis, the "idea" of "heatdeath." Modernist paranoia about the death of the world prefigures Callisto's fear of Aubade, molds her face into a death mask and forecasts his love of her as necrophilia.

In their attempt to define love so as to be certain of its saving power, the modernists only succeed in discovering the inextricable connection between love and death; the more they insist upon securing themselves against disorder, the more love itself begins to look like disorder:

Henry Adams, three generations before his own, had stared aghast at Power; Callisto found himself now in much the same state over Thermodynamics, the inner life of that power, realizing like his predecessor that the Virgin and the dynamo stand as much for love as for power; that the two are indeed identical; and that love therefore not only makes the world go round but also makes the boccie ball spin, the nebula precess. It was this latter or sidereal element which disturbed him [E: 84-85/69]

In Callisto's fearful reading, the very motion that sustains form, that supports life on earth, must also destroy it; "love" or the earth's attraction to the sun results in a transfer of heat necessary for the continuance of life, but also leads to the climactic end of all transference, the equilibrium of "heat-death." In being drawn toward its source of required heat-energy, the earth simultaneously decreases the difference in temperature needed to maintain its own form of life.

Like Aubade's notion of monumental stability, Callisto's modernist-inspired ideal of formal purity needs motion to complete it yet fears motion as depletion; outside energy is always desired to fill an insatiable sense of lack, but such energy is also feared as moving the self toward ultimate emptiness: when all the outside has been taken in, where can the constitutionally needy self look for fulfillment? The difference between self and other that love encourages Callisto to overcome in order to achieve fulfillment is also the difference that cannot be conquered if the forever self-doubting Callisto is always to have some 
new virgin from whom to gain a temporary sense of potency. Just as the earth's attraction to the sun, a movement that might be taken as the primary sign of life, can only appear as a death drive in the eyes of modernists who crave absolute security, so the love that Callisto is offered looks like death to one for whom every transfer of heat only increases a fear of the end of all transference, every distance crossed and bit of time elapsed only portends the crossing out of space and the running out of time.

Callisto's desire is thus self-thwarting in that his every hopeful movement toward a love-object is countered by a fear of motion itself: to attempt to bridge the gap between self and other is not only to admit that there exists a gap that may be unbridgeable, but also to confront the possibility that that gap may indeed be bridged, that in eliminating differences one may abolish differentiation itself. Callisto desires a successful transfer of heat between himself and the other (assuring him of his potency) or between the other and himself (filling him with power), but his irrepressible fear that any motion will destroy form, that all transference or love tends toward nondifferentiation or death, makes every attempt at communication a self-confirming prophecy of failure. The Callisto who shelters a sick bird in his arms, trying to "give it warmth" and make it "well again" (E: $83 / 68$ ), is the same sick man whose "fingers pressed the bird more firmly, as if needing some pulsing or suffering assurance of an early break in the temperature" (E: 85/70). Callisto does not know where the source of heatenergy can be found, in himself or in the other, inside or outside; his great fear is that every potentially salubrious outside is really already a dead inside, and vice versa. No prospective love coming to or from him can override his fear of the coming of the end, of coming as the end. Callisto's inability to settle for anything less than absolute certainty as to the locus of power makes any mere attempt at a transfer of energy seem fruitless; unable to tolerate the possibility of failure, Callisto ends up ensuring the necessity of failure, assuring himself that the assurance he seeks can be found nowhere.

Significantly, it is while he is lost in his reading of the despairing modernists that his situation suddenly becomes hopeless; thinking so hard about past failures to communicate, he fails to connect in the present: "Callisto, helpless in the past, did not feel the faint rhythm inside the bird begin to slacken and fail" (E: 97/84). Callisto's past reading predetermines his present (lack of) life. The bird's "heartbeat tick[ing] a graceful diminuendo down at last into stillness" (E: 97/85) is prefigured, preordained by the modernists' image of the "metronome" of death "tick[ing] behind the eyes" of any potential "partner" in love. The modernists to whom he turned for his supposedly saving idea of order make his every experience look hopelessly entropic. The more information the self feels it needs before it can safely join with the other, the less likely it is that that joining will occur. The desire for absolute confirmation of the other's compatibility destroys the very possibility of communication that it was supposed to substantiate. The heat-energy expended on gathering information about the other leaves too little left 
for an effective transfer. Aubade's attempt to ensure that the "signals" and the "noise" in a potential relationship with Callisto would be balanced according to an acceptable "ratio" burns up all the energy she might have preserved if she had been less fearful of communicating with him, just as Callisto's effort to save the bird from a present "heat-death" by trying to understand how others in "correspond[ing]" situations have dealt with the threat only wastes in a hopeless search for an infallible source of information the energy he might have devoted to warming the bird:

That precious signal-to-noise ratio, whose delicate balance required every calorie of [Aubade's] strength, seesawed inside the small tenuous skull as she watched Callisto, sheltering the bird. Callisto was trying to confront any idea of the heat-death now, as he nuzzled the feathery lump in his hands. He sought correspondences.... Callisto, helpless in the past, did not feel the faint rhythm inside the bird begin to slacken and fail. [E: 92-93, 97/79, 84]

There are thus two ways in which Callisto is "helpless in the past" having spent so much energy looking to the past in an effort to gather enough information about "heat-death" that he can be sure to defeat it, Callisto is left with too little energy to fight the battle that counts - the one in the present; and having allowed the despairing modernists to shape his understanding of the postmodern condition, Callisto has doomed himself to repeat their past helplessness. Past thinkers only confirm Callisto in his belief that complete knowledge of "heat-death" is required before the self can safely fight it. In giving him this "answer" to his quest - they insist he must keep looking for more and better answers - the modernists effectively solve Callisto's problem by proving it insoluble: once he knows that he'll never know enough about "heat-death" to be sure of defeating it, then he knows that there is no answer but death, nothing but to be defeated by $i t$. The endlessness of Callisto's search becomes its only end: because he feels he needs more information about the present, Callisto looks to the past which, instead of directing him back toward the present, toward living with the uncertainty of hope, merely extends his search indefinitely, thus providing him with certain hopelessness. Rather than think that the answer cannot be found in the past, Callisto takes its unlocatability as the answer, as evidence of a negative result. The two ways in which Callisto is "helpless in the past" are thus mutually reinforcing: expending energy on the past in order to gain information about the present yields only information about the uselessness of past expenditures of energy; the modernists merely reinforce the same fear of insufficient information that Callisto had gone to them to relieve. Callisto's search both finds examples, and is itself an example, of the useless expenditure of energy; it finds examples because it is an example (since he would never have looked to the past if he had felt that the present pro- 
vided him with enough information, Callisto is already predisposed to consider whatever information he receives to be inadequate) and it is an example because it finds examples (since Callisto only considers information about past thinkers who have wasted their time, his own consideration is bound to be a waste of time).

Information about others and the past is supposed to help Callisto save the bird, Aubade, and himself in the present; expending energy to gain knowledge is necessary to ensure a useful expenditure of energy in a successful transfer of heat (Callisto needs some idea of where the heat-source is before he can transfer it, of what "heatdeath" is before he can combat it). But there is a limit to the amount of energy at Callisto's disposal; there is a point of diminishing returns beyond which the energy spent on knowledge becomes less a prerequisite for than a preclusion of the energy needed for action. ${ }^{16}$ For Callisto knowledge and action are at odds, not only because his endless search for total knowledge voids the energy he must have to act (his means preclude his end), but also because the kind of knowledge Callisto seeks is really incompatible with action. The greater Callisto's fear of failure if he attempts a transfer of heat, the greater his desire for complete information about where to find heat and where it should go. In fact, the only kind of knowledge that would provide Callisto with the absolute guarantee of success that his fear demands is the transcendental knowledge of God, the wisdom of One who sees all because $\mathrm{He}$ is above time and beyond space. But the transfer of heat that Callisto would effect is within time and space, between live bodies. Callisto demands an otherworldly knowledge before he will act in this world, but in order to gain heavenly wisdom he must already have given up hope of worldly action; to know the effect of any attempted transfer of heat between bodies in time he must already have stepped outside the limited perspective of his own body and time. The ab-solute knowledge that is meant to ensure the continuing interdependence of bodies could only be achieved independent of the body; Callisto could ensure that he would remain a part of everything else only if he were apart from everything else. For Callisto to sea it all at once, either he must have removed himself from the motion (the transfer of heat) he would effect, or everything else must have stopped moving, in which case it would be too late for any transfer of heat. Either way, the total knowledge he seeks can only come at the end rather than renew the beginning of himself or the world. Callisto's failure to see the incompatibility between total knowledge and worldly action is closely tied to his failure to recognize the point of diminishing returns at which he must stop looking for more information or risk not having enough energy left to act: his inability to see that absolute knowledge must always be cut off from earthly interaction is the mirror of his failure to realize that worldly knowledge must always be connected with worldly action. There is no exact science of thermodynamics, only limited information that fallible scientists try to put to active use.

In each of these relationships, then, Callisto fails to find the openness necessary for communication; instead, he merely finds 
repeated his own fearful impermeability. The past to which he turns for help in his road-blocked present becomes less a detour than a dead end: the modernists reflect back to Callisto his own despairing face and make communication with the bird in the present seem impossible. Instead of opening up possibilities for present action, the past limits the present to more of the same, defines the postmodern as a repetition of modern failure. Callisto wants to use the modernists as a medium by which to reach the bird; he would put his faith in a space-time continuum where going back in time might help him cross a space in the present. But Callisto's fearful journey into the past abolishes both space and time: from his correspondence with the modernists he "learns" of every self's repeated failure to correspond with any other; from his movement back in time he "discovers" that there has never been time for movement, that there has never been movement in time. Present and future attempts will be no different from past failures to cross space; every attempt at a successful transfer of heat will always be too late to succeed. Callisto's journey back thus ends in the timelessness of an endlessly repeated failure to communicate, in the nowhere of a self that cannot find its own place because it lacks any relationship with a defining other.

What I have tried to show in the above argument is that the mediating structures Callisto uses in his effort to communicate are the obstacles to communication. Each time he turns to another context for help in escaping the binary divisions of a previous thought-structure, he merely "finds" those divisions repeated and exacerbated. The division in science, as Callisto understands it, between order and chaos is only made to seem more hopelessly irresolvable when Callisto tries to deal with it in philosophical terms. When the order-and chaos binary is aligned with the split between free will and determinism, and when fear and desire begin their predictable operation on the polarity they themselves created, Callisto's fear of a predetermined chaos gradually overwhelms any faith in a will to order, and he finally comes to believe that the only possible exercise of free will open to him is to bring chaos upon himself, just as the only way in which he can assert his order on the world is to identify that order with the chaos he fears is predetermined. Science and philosophy (or Callisto's understanding of them) only inform - rigidify and seem to lend authority to - the polarities of Callisto's consciousness; every new context in which Callisto finds himself placed (or places himself) proves to have the same binary divisions pointing to the same suicidal end.

By thinking of will or "virtu" as male like himself, Callisto tries to appropriate the power that he so desires, but the metaphor backfires: his investment in polarized gender categories brings with it a fear of the same women he had originally desired to protect with his power. Unable to believe that maleness alone guarantees power, Callisto is terrified by the thought that power is exclusively female, that only women have the power. Sexual intercourse thus becomes a threat and the only way in which he can imagine joining with the terrible female principle in nature ("fortuna") or with his female lover (Abuade) is to identify 
with their power over him by destroying himself. Both Callisto and Aubade turn to art as a model for life, but "find" instantiated there the same formal divisions each was trying to move beyond in their relationship together. The stark antithesis between artistic order and the chaos of life repeats itself in their lives as an impossible choice between a lonely self-unity and a self-destructive togetherness. In the end, the only way they can find to join the stability of form and the human warmth of emotion is to destroy themselves, thus (they hope) leaving behind all the hopelessly binary artistic, sexual, philosophcal, and scientific divisions of this world and entering another where all is one: after smashing the window to let chaos in, Aubade "turned to face [Callisto] and wait with him until the moment of equilibrium was reached, when 37 degrees Fahrenheit should prevail both outside and inside, and forever, and the hovering, curious dominant of their separate lives should resolve into a tonic of darkness and the final absence of all motion" (E: 98/85-86).

At the end as throughout the story, Pynchon describes his characters' thoughts and actions in terms of the contexts in which those characters live. Callisto and Aubade think of their suicide as a triumph over the divisive categories of the very contexts to which they had turned for help in dealing with division: order and entropy, free will and determinism, male and female will be joined at last; each character will have the stability of a work of art and at the same time each will be one with the other. In abolishing their own form and motion, space and time, these characters try to identify with the power-whatever it is - that created these divisions in the first place and can presumably reunite them at will. Unable to discover this power in any one of life's contexts, they assume that it must lie beyond life and death, in the context of contexts, and their final act of self-destruction is intended to lift them out of all of life's polarizing and hence limiting contexts to join the one true source of knowledge and power.

Pynchon's narrator stays very close to Callisto's and Aubade's perspective in the sections of the story dealing with these characters, particularly at the end, so it is surprising that no critic has ever argued that there might be some real connection between the characters' despairing attitude toward life's contexts and the attitude of Pynchon the author." Of course "Entropy" is also the story of Meatball Mulligan, who is able to achieve some kind of workable relationship between opposing forces, and critics have understandably sought to find Pynchon's own attitude there, in the positive results that can come from hard work. But the fact remains that the story ends with Callisto and with his perspective. Critics who discounted this fact upon first reading have reacted with dismay and outright disbelief at Pynchon's own statements about the meaning of his story, made recently in his "Introduction" to Slow Learner. There Pynchon consistently links his own attitudes at the time he wrote the story with those of-not Mulligan, but Callisto. Pynchon even goes so far as to say that his own apocalyptism reduced Callisto to something less than a fully human character and that this was Pynchon's own fault as an inexperienced author: 
A pose I found congenial in those days - fairly common, I hope, among pre-adults - was that of somber glee at any idea of mass destruction or decline. The modern political thriller genre, in fact, has been known to cash in on such visions of death made large-scale or glamorous. Given my undergraduate mood, Adams's sense of power out of control, coupled with [Norbert] Wiener's spectacle of universal heat-death and mathematical stillness, seemed just the ticket. But the distance and grandiosity of this led me to short-change the humans in the story. I think they come off as synthetic, insufficiently alive..$^{18}$

Richard Poirier, generally one of Pynchon's most sympathetic and perceptive critics, is completely taken aback; in a disappointed essay mockingly titled "Humans," Poirier can't help but see Pynchon as his own worst critic:

[Pynchon's] jaunty complaints in the Introduction that the stories in Slow Learner fail to provide full, lifelike characters are .... so curious and irrelevant as to suggest that he is kidding - and I am afraid he isn't-or that he is tired.... What "humans" can he be talking about? Their absence, their "short changing" of themselves is precisely the point of the story. To complain about it is to miss the point.... It is obvious that it is not Pynchon but [his main character] who is "literary" [and "scientific" and otherwise overly influenced by categories]... and that even he recognises how much he thereby loses of direct human feeling and experience. ${ }^{19}$

But does Callisto short-change himself or is he short-changed by the categories to which he turns for help? Does the fault lie in his character and in what he makes of his contexts, or in those contexts themselves, the only ones available to Callisto for the formation of his character? In my essay I have continually returned to the question of whether Callisto sees only what he is predisposed to find, or finds only what there is to see. Poirier, in flatly stating that Callisto short-changes himself, seems to me to miss the point of the story, to oversimplify the complex relationship between character and context. As I hope to have shown, Pynchon does more in "Entropy" than merely condemn Callisto for his inability to read correctly, to find in the philosophical, scientific, sexual, and literary contexts which surround him some way of healing the divisions in his life. And neither the story nor the "Introduction" to Slow Learner shows Pynchon to have a naive belief in the possibiltiy of "direct" or unmediated "human feeling and experience." The "Introduction" reveals Pynchon, like Callisto, to have spent perhaps "too much time and energy on words alone," 20 but not as having given up 
reading science, philosophy, or the $O E D$ in favor of some search for "direct" experience. The "Introduction" shows Pynchon, like Callisto, as having sometimes forgotten to check the facts in his fiction against the facts in other fiction (Pynchon mistook "grippe espagnole"'[Spanish influenza] for something much more apocalyptic), ${ }^{21}$ but not as having lost all faith in combining scientific and literary contexts in an attempt to understand the world.

Perhaps what Pynchon has said about another work of fiction can help us understand what he wanted to say about character and context in "Entropy." In reviewing a novel by his friend Oakley Hall, Pynchon directs us away from placing the whole of our blame on either one side or the other, character or context:

Tombstone, Arizona, during the 1880 's is, in ways, our national Camelot: a never-never land where American virtues are embodied in the Earps, and the opposite evils in the Clanton gang; where the confrontation at the OK Corral takes on some of the dry purity of an Arthurian joust. Oakley Hall, in his very fine novel Warlock (Viking) has restored to the myth of Tombstone its full, mortal, blooded humanity. Wyatt Earp is transmogrified into a gunfighter named Blaisdell who, partly because of his blown-up image in the Wild West magazines of the day, believes he is a hero. He is summoned to the embattled town of Warlock by a committee of nervous citizens expressly to be a hero, but finds that he cannot, at last, live up to this image; that there is a flaw not only in him but also, we feel, in the entire set of assumptions that have allowed the image to exist. It is Blaisdell's private abyss, and not too different from the town's public one. ${ }^{22}$

What Pynchon has tried to do in "Entropy" is to demonstrate precisely why Callisto's private abyss is "not too different" from our public one, why the "flaw" in his character is also a "flaw ... in the entire set of assumptions that have allowed the image [Callisto has constructed of himself] to exist." If Callisto believes that he must be the virtuous hero combatting evil entropy, this is "partly [and only partly] because" he has made the mistake of reading books that polarize reality into simplistic categories of good and evil, but also partly because he senses rightly that other people really expect him to play that role ("He is summoned to the embattled town of Warlock by a committee of nervous citizens expressly to be a hero"'). The binary thinking to which Callisto is predisposed is also-and not just coincidentally - the only kind of thinking to which every context predisposes him; the simplistic opposition between good and evil that one finds in a political thriller or western myth is "not too different" from the polarized categories that one finds everywhere in "real" people's perceptions-scientific, philosophical, and sexual-of "real" life. 
Critics who blame Callisto for short-changing himself not only miss the fact that Callisto's contexts are also to blame, but repeat the same simplistic and deadly division into "good guys" and "bad guys""Callisto is the one at fault"- for which they are blaming Callisto. Critics who suggest that all Callisto has to do is to get beyond the mediating influence of categories and find some "direct human feeling and experience" repeat the same mistake made by Callisto and other unquestioning adherents to one point of view - the mistake of believing that what they see is the unvarnished-unmediated - truth about the world and not just one perspective among the many others possible. It takes a belief in the possibility of unmediated experience for critics to be so sure that they are right about just who or what is at fault in "Entropy," about who is short-changing whom.

Pynchon's story, with its constant movement from character to context and back again, emphasizing how the one influences the other and vice versa, is intended to dispel this "never-never land" of critical certainty about right and wrong, good and evil. To be "human," as Pynchon understands it, is to be required to form one's character within certain contexts, to see the world through particular perspectives. The mistake he fears he made in his depiction of Callisto's character is in underestimating Callisto's ability to be less a "synthesi[s]" of others' views and more "a liv[ing]" human being with some free will to move among the various contexts and categories available to him without adhering completely and forever to any one of them: "[I] short-change[d] the humans in the story. I think they come off as synthetic, insufficiently alive."'23 "Entropy," Pynchon says, is itself too much like the "political thrillers" he was reading at the time: the story shows Pynchon just beginning to question his characters' unquestioning adherence to certain views of the world, just beginning to realize that he as an author can advocate a necessary but provisional belief in categories not only by showing the terrible fate of characters who believe too much in any particular set of oppositions, but also by creating characters who, like himself as author, can move in and out of contexts without placing themselves-or finding themselves placed-in any one. ${ }^{24}$

Cal Poly, San Luis Obispo

\section{NOTES}

1 Martin Seymour-Smith, The New Guide to Modern World Literature (New York: Peter Bedrick Books, 1985), p. 146.

2 Seymour-Smith, p. 146.

3 Seymour-Smith, p. 146.

4 Seymour-Smith, p. 146.

5 William M. Palter, The Grim Phoenix: Reconstructing Thomas Pynchon (Bloom. ington: Indiana UP, 1978), p. 54. 
See the most often cited study of "Entropy," now practically canonical: Robert Redfield and Peter L. Hays, "Fugue as a Structure in Pynchon's 'Entropy,' " Pacific Coast Philology 12 (1977), pp. 50-55

Critics who find irresolvable ambiguity in the conclusion to "Entropy" ignore the extremely negative tone of the story's ending. David Seed's reaction is typical of these problematic readings: "Aubade's final action [of smashing the window to let the outside in] would be a gesture of despair, but only viewed from her perspective. It could equally well be seen as a liberating gesture which has the immediate result of freeing herself and Callisto from their hothouse" (Seed, "Order in Thomas Pynchon's 'Entropy,' " Journal of Narrative Technique 11.2 [1981], pp. 148). But the ending of "Entropy" does not suggest any other "perspective." let alone one from which Aubade's action could "equally well" be seen as positive. To imagine other perspectives is to minimize both the horror and the elation of Aubade's action in her and presumably Callisto's minds. Seed has been led, by his sympathy for Aubade as a member of an oppressed people seeking liberation, to a mistaken emphasis on the differences between Aubade and Callisto and to an unlikely reading of Aubade's fate as positive; see note 13 for my reading of these characters as mirror images of each other.

For more on the idea of suicide as an attempt to conquer death, see John T. Irwin's too often neglected study, Doubling and Incest / Repetition and Revenge: A Speculative Reading of Faulkner (Baltimore: Johns Hopkins UP, 1975). A Selection, trans. Alan Sheridan [New York: Norton, 1977].)

References to Pynchon's "Entropy" are keyed to both the hardcover and paperback versions of Slow Learner, with the hardcover reference listed first, then the paperback, as in (E: 87-88/73). Pynchon, Slow Learner: Early Stories, hardcover (Boston: Little Brown, 1984); paperback (New York: Bantam, 1985). "Entropy" originally appeared in Kenyon Review 22 (1960), pp. 277-92.

My discussion of the connection between gender categories and those of science, philosophy, and psychoanalysis is indebted to the work of many feminist critics, particularly to essays like Shoshana Felman's "Rereading Femininity," Yale French Studies 62 (1981), pp. 19.44.

See Michel Foucault on knowledge as power, particularly his Surveiller et punir: Naissance de la prison (Paris: Gallimard, 1975). (Discipline and Punish: The Birth of the Prison, trans. Alan Sheridan [New York: Pantheon, 1977].)

Some critics have suggested that Pynchon's description of Aubade as being "of French and Annamese ancestry" is his way of hinting at her "exploitation by a technological colonialism," presumably represented by Callisto (Joseph W. Slade, " "Entropy" and Other Calamities," in Pynchon: A Collection of Critical Essays, ed. Edward Mendelson [Englewood Cliffs, NJ: Prentice-Hall, 1978] 78). This seems plausible, but if Aubade has been colonized by the imperialistic Callisto, she has been so thoroughly indoctrinated in Western ways that Pynchon stresses throughout her likeness to her master. Stephen P. Schuber describes Aubade's smashing of the window at the end of "Entropy" as "the first act which she initiates in the story .... and-if one pursues the neo-colonial theme-[as] a sign of her self-destructive liberation" (Schuber, "Rereading Pynchon: Negative Entropy and 'Entropy," "Pynchon Notes 13 [1983]: 57-58), but I would point out that Aubade's last action, like her others in the story, is performed at Callisto's (spoken or tacit) bidding and that it mirrors, in all its complexity, Callisto's own desire for a "self-destructive liberation." Aubade is like the Empty Ones in Gravity's Rainbow, colonized blacks who have incorporated their oppressors' complex of destructive / self-destructive tendencies and have embarked on a program of racial suicide / revenge. 
We can see another way in which Callisto and Aubade mirror each other as colonist and colonized if we consider Michael Ryan's definition of colonialism as a kind of narcissism in which the "ego" feels "jubilation at apprehending an image of its own power" (Ryan, "Self-De[con]struction," Diacritics 6.1. [1976]: 36). Callisto tries to dominate the other (woman: fortuna and Aubade) in order to assure himself of his own power, but the idea that the other may lack power on. ly makes the still uncertain Callisto fear that he himself has the same lack, so he ends up projecting complete power onto it/her ("Since [the child's fear of] the mother's lack of a penis initiates the child's castration anxiety, he protects himself by denying her castration.... The child disavows the mother's lack of a phallus, her castration which, by implication, is his own, by being the phallus for her [or by assigning the phallus to her]"-Ryan 35). Aubade's narcissism mirrors Callisto's: like him she cannot tolerate any breach in the wholeness of her body (power), so she identifies with-by obeying - the power of her master Callisto, and when his strength gives out before opposing forces, she lets those forces engulf her (she smashes the window) in order to identify with them.

The apocalyptism of the major modernist (and not only modernist) writers and critics, stemming from their paranoid opposition between artistic "order" and the "chaos" of life, receives perhaps its fullest discussion in Frank Lentricchia's After the New Criticism (Chicago: $U$ of Chicago P, 1980).

David Seed's neat formulation of the problem - "Callisto seems to be suffering from a hand-me-down pessimism, an ersatz gloom without any roots in his own experience" (Seed, 143) - is just too simple: although Pynchon obviously means to imply that Callisto is in some sense reading about life rather than "seeing" it for himself, Pynchon is too aware of the fact that every view of life is structured through some context ever to suggest that all Callisto needs is some unmediated experience. As I indicate at the end of this essay, I think Pynchon suggests, by emphasizing the danger of adhering to a single thought-structure, that we play one context off another without fixing on any one as the absolute truth, but using each for what it has to offer-here and now.

Readers familiar with Pynchon will recognize that he is here is alluding to the Maxwell-Brillouin controversy: whereas the physicist Clerk Maxwell maintained the possibility of a perpetual-motion machine kept going by a subject who com. batted entropy by sorting the machine's molecules into their proper places, Leon Brillouin argued that the energy expended by the subject to determine which molecules were where would leave too little energy left for sorting those molecules and that a perpetual-motion machine was thus impossible.

Joseph Tabbi and David Seed, for example, who have written two of the most recent and most perceptive essays on "Entropy," either draw too simple a contrast between Callisto's and Pynchon's attitudes (Tabbi) or can find nothing but irresolvable ambiguity in the story (Seed). Tabbi: "Aubade and Callisto exhaust their creative energies in trying to preserve the delicate balance and selfenclosure of their isolated world. Pynchon as a writer, however, incorporates these motifs of merging orders into the structure of his narrative, and in so doing avoids the kinds of static and enclosed perception that Adams so thoroughly criticises. Pynchon at the outset was working to create an imaginative order in art that could engage randomness and indeterminacy in modern life and in the changing physical world" (Tabbi, "Merging Orders: The Shaping Influence of Science on 'Entropy," "Pynchon Notes 15 [1984]: 67).

Seed: "Formally speaking the story has begun from rest and comes back to it at the end. In that sense it seems satisfyingly symmetrical. But, because music is a non-conceptual medium, the use of music to create form in the story does not carry with it any epistemological implications. ... "Entropy" examines various notions of order and disorder in such a way as to make it very difficult to locate Pynchon's own view-point. Music is of course non-verbal and so an ideal means of binding his story together without committing himself to any one view. point.....Pynchon's story forces a relativistic view-point on to the reader, which 
acts against a final resolving certainty, or one definite moral direction" (Seed 150-51).

Pynchon, Slow Learner 13/xxiii.

Richard Poirier, "Humans," rev. of Slow Learner, by Thomas Pynchon, London Review of Books 24 Jan. 1985: 18-19. Poirier's last comment ("It is obvious that it is not Pynchon....") actually refers to another Pynchon short story, "The Small Rain," but the statement is right in line with his preceding comments on "Entropy" and hence equally applicable to that story. Like all of Poirier's work as a critic, his essay "Humans" is extremely complex, and I am aware that I do him some injustice by excerpting even a passage this long from the whole of his essay.

Pynchon, Slow Learner 15/xxv.

21 "I must have thought this [grippe espagnole] was some kind of post-World War I spiritual malaise or something" (Pynchon, Slow Learner 16/xxvi).

Pynchon, rev. of Warlock, by Oakley Hall, Holiday 38.6 (1965): 164-65.

Pynchon, Slow Learner 13/xxiii.

24 Tyrone Slothrop of Gravity's Rainbow may be an example of this last kind of character. Although Slothrop, like Callisto, may have been led (or let himself be led) to self-destruction by the ominously aligned categories surrounding him, Pynchon also leaves open the possibility that Slothrop has managed, with some free will, to escape being fixed in or by any one category. 